\title{
SISTEM INFORMASI PENGOLAHAN DATA ADMINISTRASI KEPENDUDUKAN PADA KANTOR DESA PUCUNG KARAWANG
}

\author{
${ }^{1}$ Mita Agnitia Lestari, ${ }^{2}$ Muhamad Tabrani, ${ }^{3}$ Surtika Ayumida \\ E-mail : ${ }^{1}$ mitaagni0808@bsi.ac.id, ${ }^{2}$ muhamad.mtb@ nusamandiri.ac.id, ${ }^{3}$ surtika.skm@bsi.ac.id
}

\begin{abstract}
Abstrak
Kantor Desa Pucung sangat membutuhkan adanya sistem informasi guna mempercepat proses pendataan, mencetak surat, mencari data dan membuat laporan sehingga kepuasan dalam pelayanan tidak hanya dapat dirasakan oleh masyarakat tetapi seluruh staff juga dapat merasakannya karena pekerjaan menjadi lebih efektif dan efisien. Peneliti membuat sistem informasi mengenai Pengolahan Data Administrasi Kependudukan pada Kantor Desa Pucung, yang sebelumnya telah dilakukan pengamatan terhadap kegiatan yang berjalan disana, wawancara dengan beberapa aparat desa dan studi pustaka. Sistem Pengolahan Data ini menggunakan metode Waterfall sebagai metode pengembangan perangkat lunak dengan tahap awal yaitu Analisa Kebutuhan Perangkat Lunak dan tahap akhir yaitu Desain, sistem ini telah peneliti analisa mengenai apa saja yang dibutuhkan oleh pengguna sehingga sistem ini dapat bermanfaat untuk pengguna. Dalam Sistem ini pengguna dapat dengan mudah mencari data, memasukkan dan menyimpan data dengan sistem keamanan yang menjamin, mencetak surat dengan cepat dan menghasilkan laporan dengan hasil yang akurat. Perancangan Sistem Pengolahan Data Administrasi Kependudukan ini merupakan solusi terbaik untuk memecahkan permasalahan-permasalahan yang ada di Kantor Desa Pucung Karawang. Dengan sistem ini, kinerja pelayanan akan meningkat dan menjadi lebih cepat, mudah dan rapih dibandingkan sistem yang terdahulu.
\end{abstract}

Kata Kunci: Perancangan Sistem, Pengolahan Data Administrasi Kependudukan, Kantor Desa

\begin{abstract}
Pucung Village Office is in dire need of an information system to accelerate the data collection process, print letters, search for data and make reports so that satisfaction in service can not only be felt by the community but all staff can also feel it because the work becomes more effective and efficient. The author made an information system on Processing Population Administration Data at the Pucung Village Office, which had previously been observed on the activities that went on there, interviews with several village officials and literature studies. This Data Processing System uses the Waterfall method as a software development method with the initial stages namely Software Needs Analysis and the final stage, Design, this system has been analyzed by the user about what is needed by the user so that this system can be useful for users. In this system, users can easily search data, enter and store data with a security system that guarantees, prints letters quickly and produces reports with accurate results. The Design of Population Administration Data Processing System is the best solution to solve the problems in the Pucung Karawang Village Office. With this system, service performance will increase and become faster, easier and tidy than the previous system.
\end{abstract}

Keywords: System Design, Population Administration Data Processing, Village Office

Jurnal Interkom Vol. 13 No. 3 - Oktober 2018 


\section{Pendahuluan}

Kemajuan teknologi informasi saat ini telah berkembang secara pesat, instansi pemerintahan dan swasta sudah seharusnya memanfaatkan komputer sebagai alat bantu yang akan memperbaiki sistem dalam proses pencatatan maupun pengolahan data yang sesuai dengan perkembangan teknologi sekarang. Kelurahan (kantor desa) merupakan sebuah daerah administratif di wilayah Indonesia yang berada di bawah wilayah tingkat kecamatan dan dipimpin oleh seorang lurah atau kepala desa. Seluruh data dari jenis pelayanan ataupun pengolahan data administrasi kependudukan pada kantor desa harus dibuat dengan benar, disusun dengan rapi dan dijaga dengan sebaikbaiknya, sehingga dapat bermanfaat jika dikemudian hari dibutuhkan untuk pembangunan desa ataupun hal penting lainnya. Berdasarkan dari prinsip pelayanan publik dalam keputusan Menteri PAN Nomor: 63/KEP/M.PAN/7/2003 tentang Pedoman Penyelenggaraan Pelayanan Publik sebagai berikut:

a. Kesederhaan pelayanan

b. Kejelasan dan kepastian pelayanan

c. Keamanan dalam Pelayanan

d. Keterbukaan dalam pelayanan

e. Efesiensi dalam pelayanan

f. Ekonomis dalam Pelayanan

g. Keadilan yang merata dalam pelayanan

h. Ketepatan Waktu dalam pelayanan

Kantor Desa Pucung masih menggunakan Ms.Excel, Ms.Word, buku besar, formulir untuk proses pencatatan dan proses pengolahan data administrasi kependudukan. Hal ini membuat proses pelayanan penduduk, pencatatan data penduduk dan pengelolaan lainnya menjadi sangat lambat sehingga penduduk merasa terlalu banyak membuang waktu untuk pelayanannya. Kantor Desa Pucung juga masih menyimpan data dalam bentuk berkas-berkas yang disusun dalam sebuah lemari khusus, hal ini mempersulit pencarian data baik data yang lama maupun baru ketika sewaktu-waktu dibutuhkan. Sehingga tidak sesusai dengan keputusan Menteri PAN Nomor: 63/KEP/M.PAN/7/2003 tentang Pedoman Penyelenggaraan Pelayanan Publik
Dengan sistem Informasi pengolahan data administrasi kependudukan, kepuasan dalam proses pelayanan tidak hanya dapat dirasakan oleh penduduk yang berperan sebagai pelanggan, tetapi juga dapat dirasakan oleh seluruh staff di Kantor Desa Pucung karena proses pencatatan dan penyimpanan menjadi lebih mudah untuk dikelola. Oleh karena itu, dibuatkan perancangan sistem untuk pengolahan data administrasi kependudukan menggunakan bahasa pemrograman Java yang diharapkan dapat meningkatkan kinerja pelayanan, mempermudah proses pengolahan data dan memperingan proses pembuatan laporan di Kantor Desa Pucung yang berada di Karawang.

\section{Tinjauan Pustaka}

\section{Pengertian Sistem}

Menurut

Pratama

mengemukakan bahwa, "Sistem didefinisikan sebagai sekumpulan prosedur yang saling berkaitan dan saling terhubung untuk melakukan suatu tugas bersama-sama".

\section{Pengertian Informasi}

Menurut Pratama

mengemukakan bahwa, "Informasi merupakan hasil pengolahan data dari satu atau berbagai sumber, yang kemudian diolah, sehingga memberikan nilai, arti dan manfaat".

Menurut Darmawan dan Fauzi (2013:26), "Informasi adalah data yang telah diolah menjadi sebuah bentuk yang berarti bagi penerimanya dan bermanfaat dalam pengambilan keputusan saat ini atau saat yang akan datang".

Apabila di sintesakan dari kedua kutipan diatas, peneliti dapat menyimpulkan bahwa informasi adalah hasil pengolahan data yang hasilnya akan bermanfaat dan berguna bagi orang yang menerima informasi tersebut.

\section{Pengertian Sistem Informasi}

Menurut

Hutahaean

(2015:13) mengatakan bahwa, "sistem informasi adalah suatu sistem didalam suatu organisasi yang mempertemukan kebutuhan pengelolaan 
transaksi harian, mendukung operasi, bersifat manajerial, dan kegiatan strategi dari suatu organisasi dan menyediakan pihak luar tertentu dengan laporan-laporan yang dibutuhkan”.

\section{Administrasi Data Kependudukan}

(Marbun, Posuma, \& Rompas, 2015) adalah rangkaian kegiatan penataan dan penerbitan dalam penerbitan dokumen dan Data Kependudukan melalui Pendaftaran Penduduk, Pencatatan Sipil, Pengelolaan Informasi Administrasi Kependudukan serta pendayagunaan hasilnya untuk pelayanan publik dan pembangunan sektor lain.

\section{Entity Relationship Diagram (ERD)}

Menurut Yanto (2016:32), "ERD adalah suatu diagram untuk menggambarkan desain konseptual dari model konseptual suatu basis data relasional. ERD juga merupakan gambaran yang merelasikan antara objek yang satu dengan objek yang lain dari objek di dunia nyata yang sering dikenal dengan hubungan antar entitas".

\section{Logical Record Structure (LRS)}

Menurut Fridayanthie dan Mahdiati (2016:132), "Logical Record Structured (LRS) adalah representasi dari struktur record-record pada tabel-tabel yang terbentuk dari hasil relasi antar himpunan entitas. Menentukan kardinalitas, jumlah tabel, dan ForeignKey (FK)".

Berikut adalah cara membentuk skema database atau LRS (Logical Record Strutured) berdasarkan Entity Relationship Diagram:

a. Jika relasinya satu-ke-satu, maka foreign key diletakan pada salah satu dari dua entitas yang ada tau menyatukan kedua entitas tersebut.

b. Jika relasinya satu-ke-banyak, maka foreign key diletakan pada entitas Many.

c. Jika relasinya banyak-ke-banyak, maka dibua "file konektor" yang berisi dua foreign key yang berasal dari kedua entitas.

\section{Pengertian Unified Modelling Language} (UML)

Menurut Fadallah dan Rosyida (2018:62), "UML merupakan bahasa visual untuk pemodelan dan komunikasi mengenai sebuah sistem dengan menggunakan diagram dan teksteks pendukung". "Unified Modeling Language (UML) adalah bahasa untuk menspesifikasi, memvisualisasikan, serta mengontruksi bangunan dasar sistem perangkat lunak, termasuk melibatkan pemodelan aturan-aturan bisnis". UML menyediakan beberapa diagram visual yang menunjukkan berbagai aspek dalam sistem, ada beberapa diagram yang disediakan dalam UML, antara lain:

1. Use case diagram menyajikan interaksi antara use case dan aktor. Dimana, aktor dapat berupa orang, peralatan atau sistem lain yang berinteraksi dengan sistem yang sedang dibangun. Use case menggambarkan fungsional sistem atau persyaratanpersyaratan yang harus dipenuhi sistem dari pandangan pemakai.

2. Activity diagram menggambarkan aliran fungsional sistem. Pada tahap pemodelan bisnis, diagram aktivitas dapat digunakan untuk menunjukkan aliran kerja bisnis. Dapat juga digunakan untuk menggambarkan aliran kejadian dalam use case.

3. Sequence diagram digunakan untuk menunjukkan aliran fungsionalitas dalam use case. Setiap objek yang terlibat dalam diagram use case digambarkan dengan garis putus-putus vertikal, kemudian message yang dikirim oleh objek digambarkan dengan garis horizontal secara kronologis dari atas ke bawah.

4. Class diagram menunjukkan interaksi antar kelas dalam sistem. Diagram kelas dibangun berdasarkan diagram use case dan diagram sekuensial yang telah dibuat sebelumnya. Kelas memiliki tiga area pokok yaitu : Nama (stereotype), Atribut dan Metode. Atribut dan Metode dapat memiliki salah satu sifat berikut:

a. Private, tidak dapat dipanggil dari luar kelas yang bersangkutan.

b. Protected, hanya dapat dipanggil oleh kelas yang bersangkutan dan anak-anak yang mewarisinya.

c. Public, dapat dipanggil oleh siapa saja. 


\section{Metode Penelitian}

Metode penelitian merupakan langkah penting dalam penyusunan sistem khususnya bagi perancangan sistem. Metode yang digunakan oleh Peneliti terdiri dari dua metode yaitu metode pengembangan perangkat lunak dan metode pengumpulan data sebagai berikut:

\section{A. Metode Pengembangan Perangkat \\ Lunak}

Peneliti menggunakan metode pengembangan perangkat lunak dengan model waterfall sebagai dasar perancangan sistem. Menurut Sukamto dan M. Shalahuddin (2018:28), tahap-tahap waterfall model terdiri dari lima (5) tahapan, namun Peneliti hanya menggunakan dua (2) tahapan dari semua tahapan yaitu: Analisa Kebutuhan Perangkat Lunak dan Desain.

\section{B. Teknik Pengumpulan Data}

Hal pertama yang dilakukan dalam analisa sistem adalah melakukan pengumpulan data. Adapun teknik yang digunakan untuk mendapatkan sebagai berikut:

1. Pengamatan (Observation)

Metode ini peneliti gunakan untuk melakukan pengamatan bagaimana kegiatan dari Pengolahan Data Administrasi Kependudukan yang berjalan di Kantor Desa Pucung Karawang.

2. Wawancara (Interview)

Peneliti melakukan tanya jawab seputar kegiatan yang berhubungan dengan pengolahan data administrasi kependudukan kepada Ibu Julaeha yang menjabat sebagai Sekretaris Desa, Ibu Mariah yang menjabat sebagai Kepala Seksi Pemerintahan dan Staff di Kantor Desa Pucung Karawang guna mendapatkan informasi yang lebih jelas dan lengkap terkait hal yang belum peneliti ketahui.

3. Studi Pustaka

Selain melakukan kegiatan tersebut, peneliti juga melakukan studi kepustakaan untuk menambah informasi berupa teori dengan cara pengumpulan data-data yang didapat dari buku-buku dan tulisan yang bersumber dari internet.

\section{Hasil Penelitian dan Pembahasan}

\section{Use Case Diagram}

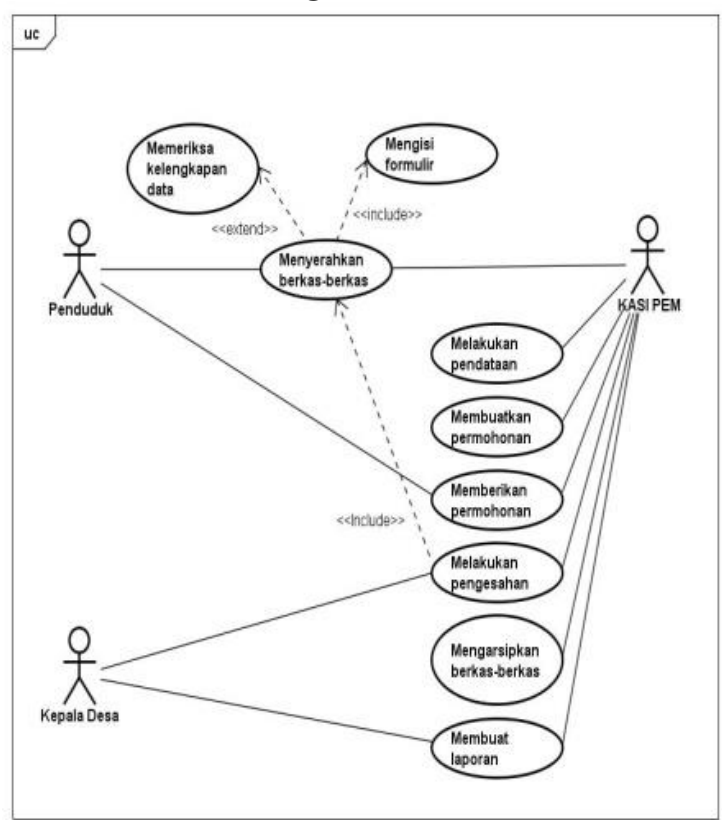

Gambar 1. Use Case Diagram Sistem Berjalan

\section{Rancangan Sistem Usulan \\ Analisa Kebutuhan}

A. Kebutuhan Sistem

Untuk menyelesaikan permasalahan yang terkadang penduduk keluhkan, sistem ini diharapkan dapat memberikan solusi yang dibutuhkan oleh pengguna. Sistem ini menyediakan beberapa form yang mudah digunakan sehingga dapat mempercepat proses pelayanan dengan data yang akurat dan mempermudah pengguna mendapatkan informasi yang dibutuhkan. Dengan menggunakan sistem ini, bantuan database dapat menunjang keamanan data yang tersimpan. 
1. Rancangan Diagram Use Case

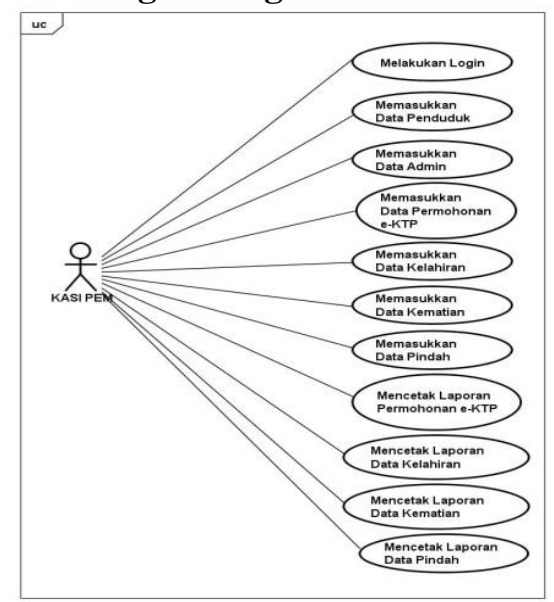

Gambar 2. Use Case Diagram Sistem Usulan

\section{Rancangan Prototype}

Berikut adalah rancangan prototype dari program Pengolahan Data Administrasi Kependudukan pada Kantor Desa Pucung Karawang:

\section{Form Login}

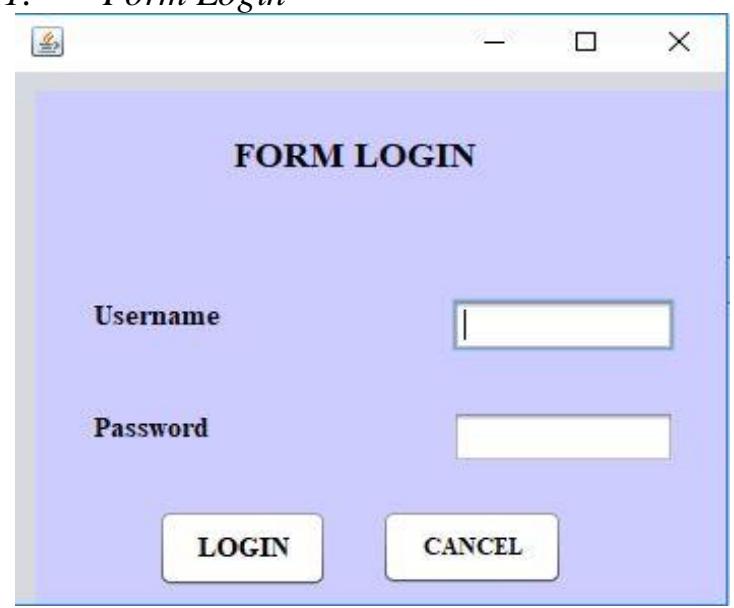

Gambar 3. Form Login

2. Form Menu Utama

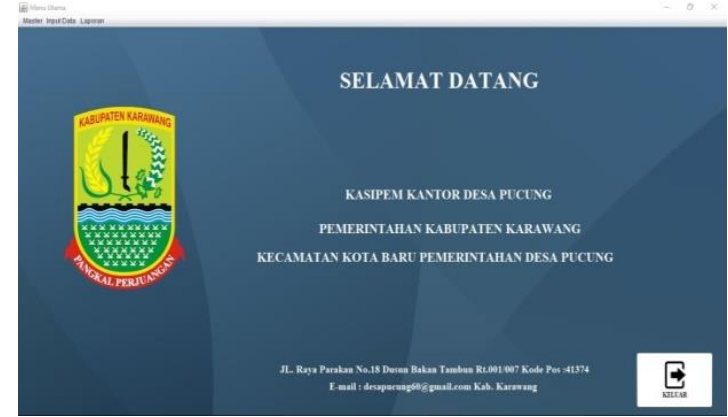

Gambar 4. Form Menu Utama

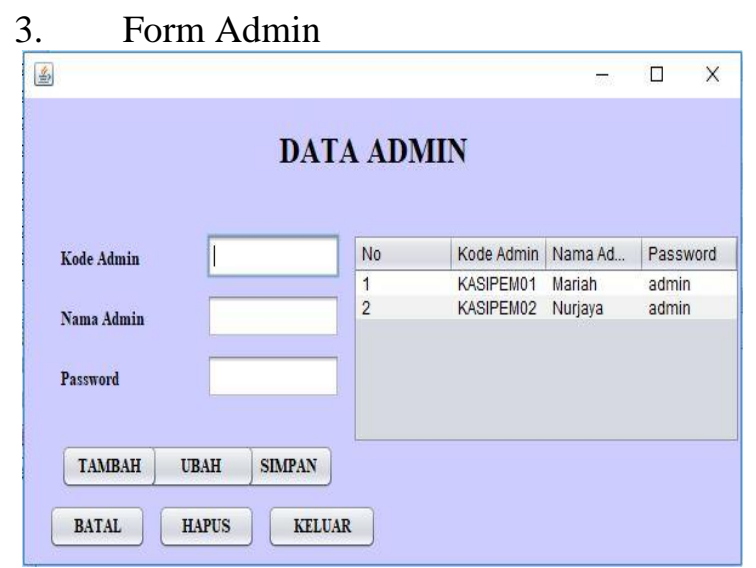

Gambar 5. Form Data Admin

4. Form Data Penduduk

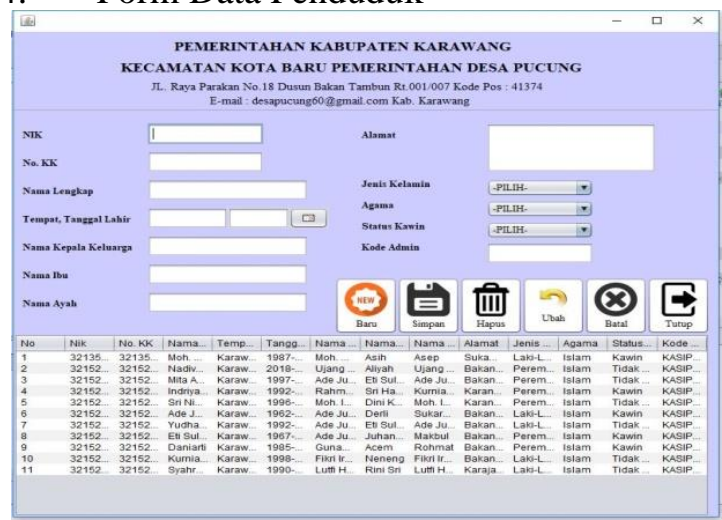

Gambar 6. Form Data Penduduk

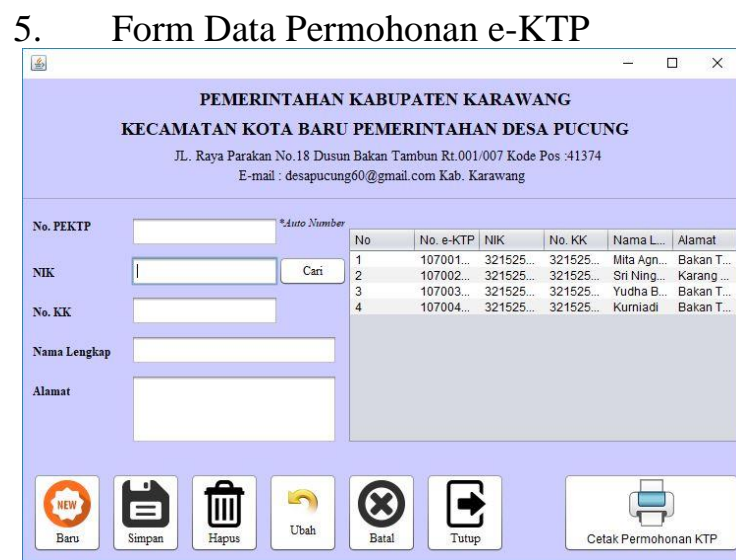

Gambar 7. Form Data Permohonan e-KTP 
6. Form Data Kelahiran

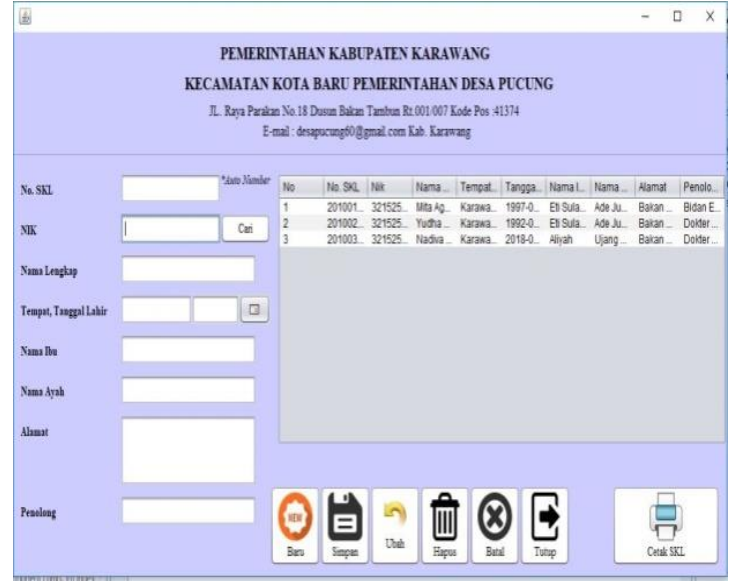

Gambar 8. Form Data Kelahiran

7. Form Data Kematian

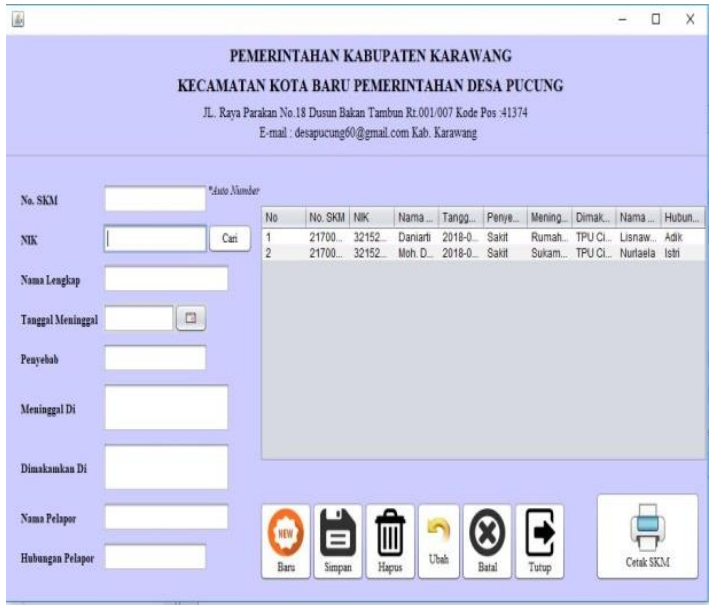

Gambar 9. Form Data Kematian

8. Prototype Form Data Pindah

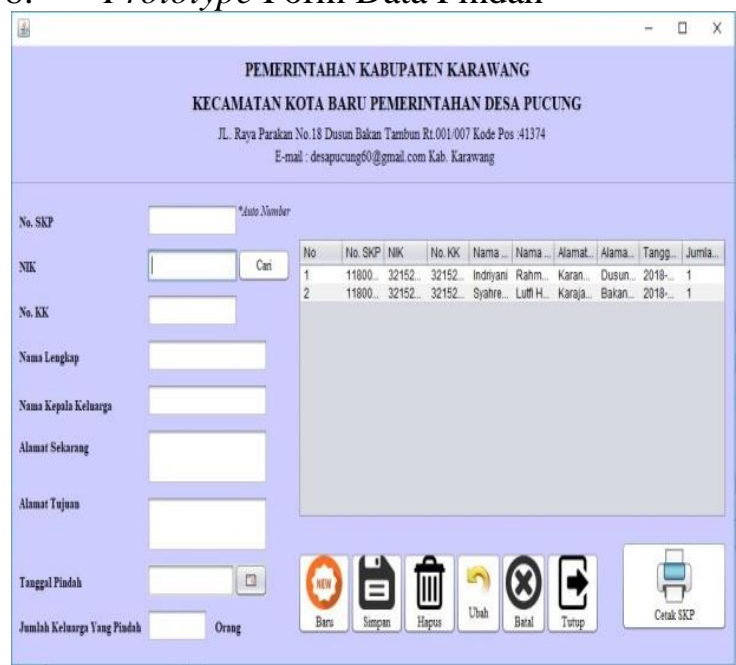

Gambar 10. Form Data Pindah
Perancangan Perangkat Lunak

1. Entity Relationship Diagram (ERD)

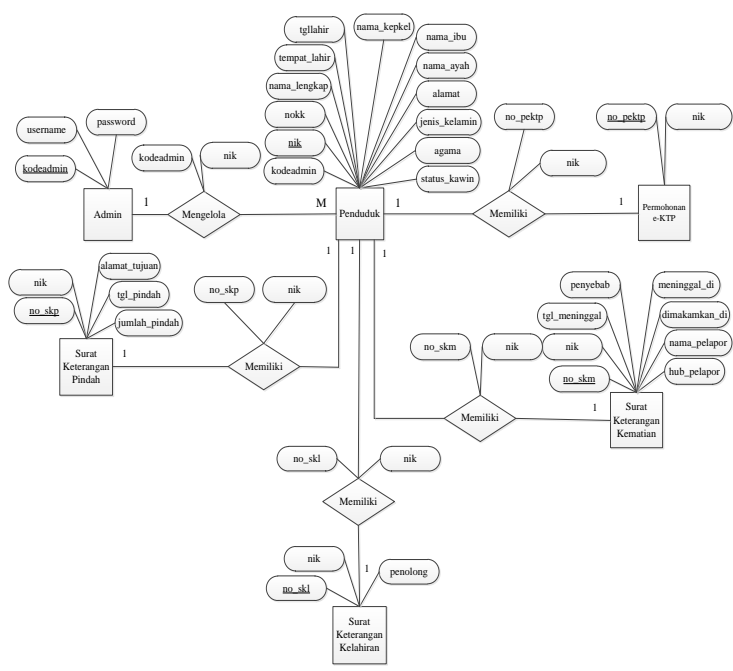

Gambar 11. Entity Relationship Diagram

2. Logical Record Structure (LRS)

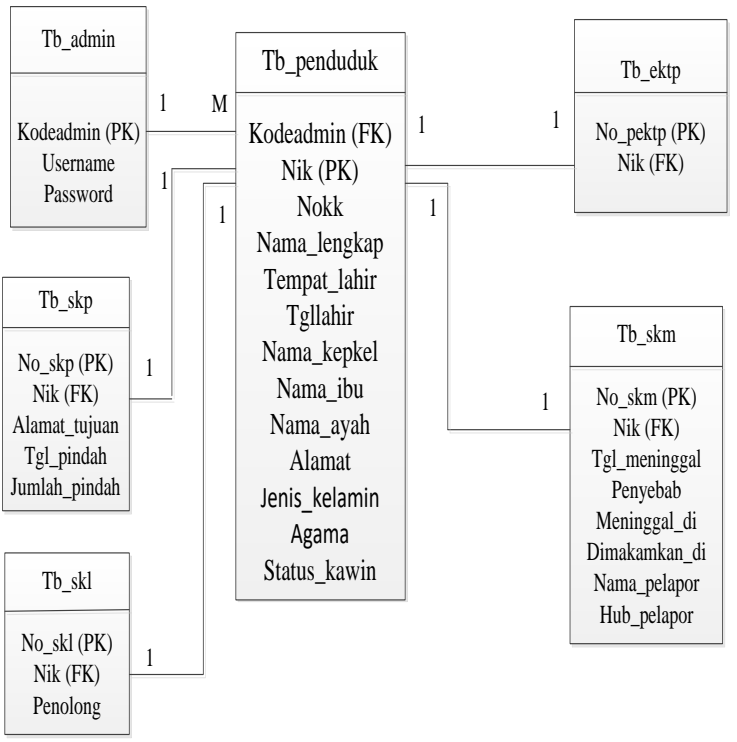

Gambar 12. Logical Record Structure (LRS) 


\section{Class Model / Class Diagram}

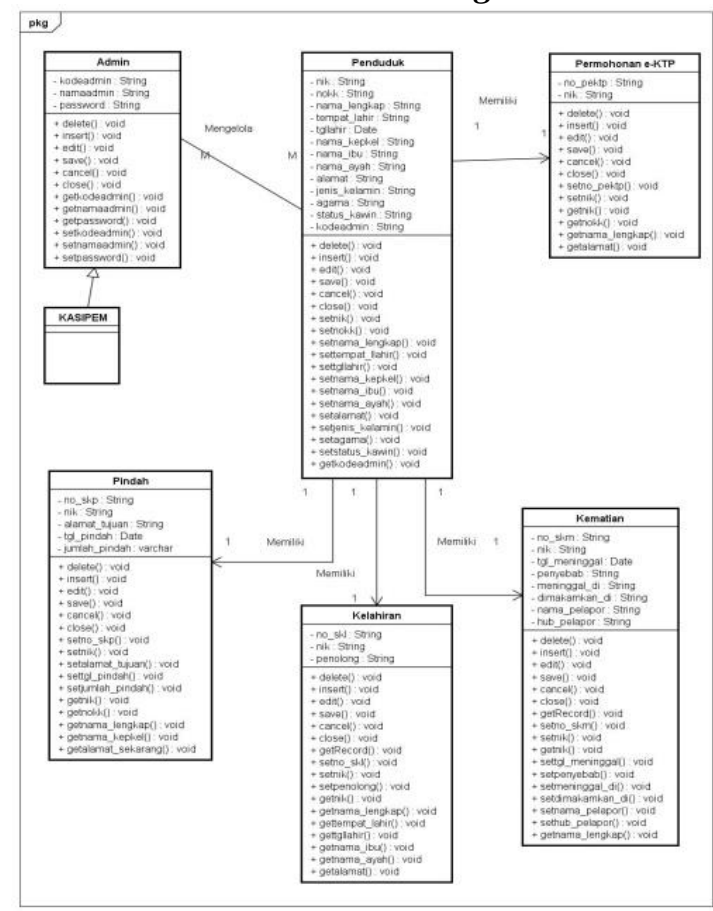

Gambar 13. Class Model / Class Diagram

4. Sequence Diagram

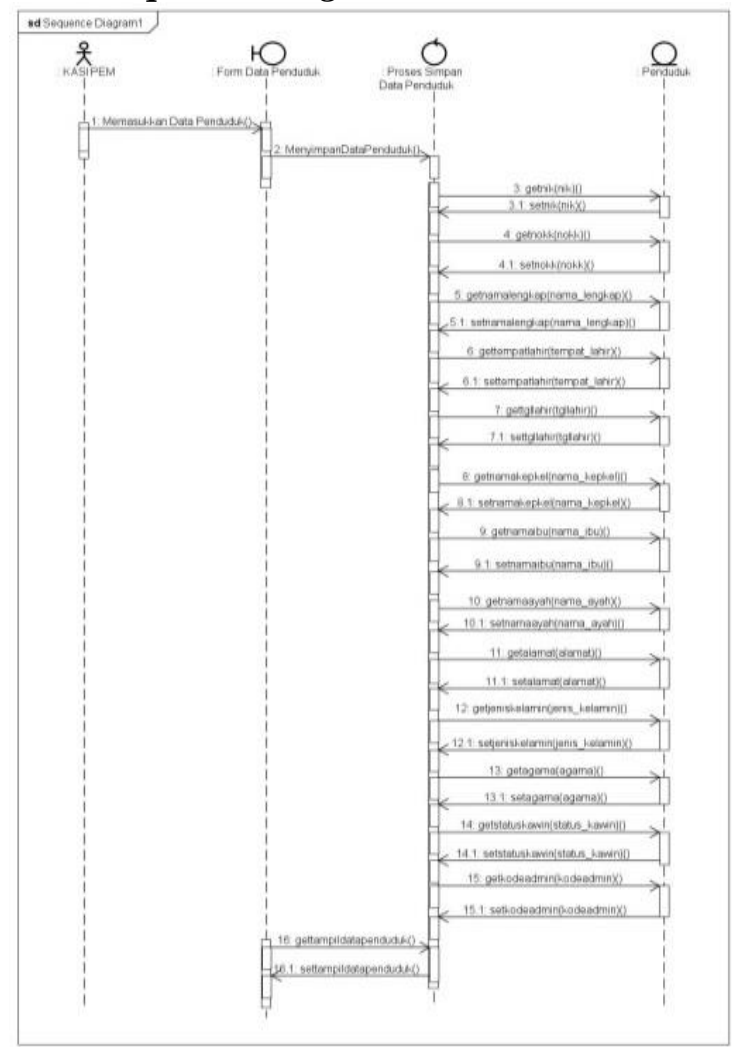

Gambar 14. Sequence Diagram Memasukkan Data Penduduk

\section{Kesimpulan dan Saran}

\section{Kesimpulan}

Setelah peneliti melakukan Perancangan Sistem Pengolahan Data Administrasi Kependudukan pada Kantor Desa Pucung Karawang menggunakan bahasa pemrograman Java dan database Mysql. Dari hasil penelitian peneliti mendapat kesimpulan sebagai berikut:

1. Dengan sistem komputerisasi, proses pengolahan data dari administrasi kependudukan menjadi semakin mudah, penyimpanan data yang sebelumnya disusun dalam lemari khusus dengan bentuk berupa buku agenda/buku register maka dengan sistem ini data akan lebih rapih karena disimpan dalam database sehingga dapat mencegah hilangnya data.

2. Data dari proses pencatatan yang sebelumnya dicatat dalam buku besar/register menjadi lebih terjaga keamanannya setelah menggunakan komputerisasi, dan data menjadi semakin mudah ditemukan ketika dibutuhkan untuk membuat laporan maupun untuk pengecekan data.

3. Sistem ini dapat meningkatkan kinerja aparat desa di Kantor Desa Pucung dengan memberikan kemudahan dalam mengolah data, menyimpan data, membuat permohonan dan membuat laporan.

\section{Saran}

Dari hasil pembuatan penelitian ini, peneliti memberikan saran untuk meningkatkan sistem yang telah diterapkan:

1. Sebelum diimplementasikan, sebaiknya dilakukan pelatihan terlebih dahulu agar KASI PEM sebagai pengguna dapat memahami dengan benar bagaimana menggunakan aplikasi ini sesuai dengan kebutuhan sehingga dapat memelihara program ini dengan baik.

2. Back-up file sebaiknya dilakukan setiap akhir bulan untuk mencegah adanya data yang hilang.

3. Sistem ini diperlukan adanya pengembangan fungsi-fungsi tambahan salah satunya fungsi untuk menghitung jumlah penduduk berdasarkan jenis kelamin, agama dan status perkawinan 
sehingga pengguna dapat mengetahui pertumbuhan penduduk melalui sistem.

4. Diharapkan selalu dilakukan perubahan atau pengembangan terhadap sistem ini sesuai dengan perkembangan zaman dan kebutuhan yang diperlukan, contohnya dengan mengembangkan sistem menjadi berbasis online (web).

\section{Daftar Pustaka}

Damayanti, I., dan Riyanto, A. (2013). Kajian Sistem Informasi Harga Pokok Produksi Pada Aneka Bolu Alam Jaya Sukabumi, 17-24. Diambil dari : http://seminar.bsi.ac.id/simnasiptek/index .php/simnasiptek-2013/article/view/35

Darmawan, Deni., dan Fauzi, N.K. (2013). Sistem Informasi Manajemen. Bandung: PT. Remaja Rosdakarya Offset.

Fadallah, M. F., dan Rosyida, S. (2018). Program Pemesanan Percetakan Berorientasi Objek dengan Pemodelan Unified Modeling Language, (1), 61-70. Diambil dari https://repository.bsi.ac.id/index.php/repo /viewitem/624

Fiqran, Muhamad., Arfhan Prasetyo dan Baginda Oloan Lubis. (2015). Sistem Informasi Inventory Pada PT. Masterweb Network Jakarta, 1-10. Diambil dari : https://repository.bsi.ac.id/index.php/repo /viewitem/756

Fujiyati, O. Y. (2015). Sistem Informasi Pengolahan Data Kependudukan Desa Purwoasri, 7(1), 1-8. Diambil dari:http://ijns.org/journal/index.php/spee $\mathrm{d} /$ article/view/1303

Hutahaean, Jeperson. (2015). Konsep Sistem Informasi. Yogyakarta: CV. Budi Utama.

Kusumawati, A., Pudjiantoro, T. H., dan Nursantika, D. (2017). Sistem Informasi Kependudukan Pada Kecamatan Kadungora Kabupaten Garut, 27-34. Diambil dari : http://www.senaski.unikom.ac.id/arsip/pr osiding/sistem-informasi-kependudukan-pada-kecamatan-kadungora-kabupaten-garut-10
Keputusan Menteri PAN Nomor: 63/KEP/M.PAN/7/2003 tentang Pedoman Umum Penyelenggaraan Pelayanan Publik

Lestari, D.E. (2016). Pelayanan administrasi kependudukan pada kantor dinas kependudukan dan pencatatan sipil di kota bontang, 4(1), 2618-2631. Diambil dari : http://ejournal.an.fisip-unmul.ac.id/

Marbun, S., Jhoni H.P., dan Sonny, R. (2015). Kinerja Pegawai dalam Meningkatkan Pelayanan Administrasi Kependudukan di Dinas Kependudukan dan Catatan Sipil Kota Manado, 1-8. Diambil dari : https://ejournal.unsrat.ac.id/index.php/JA $\mathrm{P} /$ article/view/7750

Pamungkas, A.J. (2017). Pengantar dan Implementasi Basis Data. Yogyakarta: CV. Budi Utama.

Pratama, E.A.P.I. (2014). Sistem Informasi dan Implementasinya. Bandung: Penerbit Informatika.

Sukamto, A.R., dan M. Shalahuddin. (2018). Rekayasa Perangkat Lunak. Bandung: Penerbit Informatika.

Sugianur., dan Nurcahyanti, Y. (2015). Sistem informasi pendataan penduduk desa ganepo berbasis dekstop, 1-8. Diambil dari

http://jurnal.unda.ac.id/index.php/Jpdf/art icle/view/89

Supriyanta., dan Nisa, K. (2015). Perancangan Website Desa Wisata Karangrejo Sebagai Media Informasi Dan Promosi, 3(1), 3540. Diambil dari : https://repository.bsi.ac.id/index.php/repo /viewitem/716

Urva, G., dan Siregar, H. F. (2015). Pemodelan UML E- Marketing Minyak Goreng, (9), 92-101. Diambil dari : http://is.its.ac.id/pubs/oajis/index.php/ho me/detail/1464/Pemodelan-UML-EMarketing-Minyak-Goreng

Yanto, Robi. (2016). Manajemen Basis Data Menggunakan Mysql. Yogyakarta: CV. Budi Utama. 